\title{
APLIKASI PENGENALAN PENUTUR PADA IDENTIFIKASI SUARA PENELEPON MENGGUNAKAN MEL-FREQUENCY CEPSTRAL COEFFICIENT DAN VECTOR QUANTIZATION (Studi Kasus : Layanan Hotline Universitas Pembangunan Nasional "Veteran" Yogyakarta)
}

\author{
Muhammad Fahim Rasyid(1), Herlina Jayadianti(2), Herry Sofyan ${ }^{(3)}$ \\ Jurusan Teknik Informatika Fakultas Teknik Industri UPN "Veteran" Yogyakarta \\ Jl. Babarsari 2 Tambakbayan Yogyakarta \\ e-mail: fahim.rasyid45@gmail.com ${ }^{(1)}$, herlinajayadianti@gmail.com ${ }^{(2)}$, herrysofyan@gmail.com ${ }^{(3)}$
}

\begin{abstract}
Everyone is able to access Universitas Pembangunan Nasional "Veteran" Yogyakarta's hotline services. Staff and employees using the services to share informations with other departments in the rectorate building. Caller have to identified by the officer to comunicate with intended department. The term of identity such as name, position, and origin of the majors or section are asked during identification process. There is no physical and computer database record of identification results yet. These problems cause hotline services officer do not have any evidiance for incorrect identification of the caller. This research focus to decrease these problems using speaker recognition technology. Voice frequency was extracted using Mel-Frequency Cepstral Coefficient (MFCC) into Mel Frequency Cepstrum Coefficients. Employees training data coefficients compared to caller voice coefficients using Vector Quantization (VQ) method. Speaker recognition application was identified caller voice with $80 \%$ accuracy at threshold value of 25.
\end{abstract}

Keywords: Hotline, Speaker Recognition, Frequency, Mel-Frequency Cepstral Coefficient (MFCC), Vector Quantization (VQ)

\begin{abstract}
Abstrak
Layanan hotline Universitas Pembangunan Nasional "Veteran" Yogyakarta merupakan layanan yang dapat digunakan oleh semua orang. Layanan tersebut digunakan dosen dan pegawai untuk berbagi informasi dengan bagian-bagian yang berlokasi di gedung rektorat. Penelepon dapat berkomunikasi dengan bagian yang dituju apabila telah teridentifikasi oleh petugas layanan hotline. Terminologi identitas yang terdiri dari nama, jabatan serta asal jurusan atau bagian ditanyakan saat proses identifikasi. Tidak terdapat catatan hasil identifikasi penelepon baik dalam bentuk fisik maupun basis data yang terekam pada komputer. Hal tersebut mengakibatkan tidak adanya dokumentasi yang dapat dijadikan barang bukti untuk menindak lanjuti kasus kesalahan identifikasi. Penelitian ini fokus untuk mengurangi resiko kesalahan identifikasi penelepon menggunakan teknologi speaker recognition. Frekuensi suara diekstraksi menggunakan metode Mel-Frequency Cepstral Coefficient (MFCC) sehingga dihasilkan nilai Mel Frequency Cepstrum Coefficients. Nilai Mel Frequency Cepstrum Coefficients dari semua data latih suara pegawai Universitas Pembangunan Nasional "Veteran" Yogyakarta kemudian dibandingkan dengan sinyal suara penelpon menggunakan metode Vector Quantization (VQ). Aplikasi pengenalan penutur mampu mengidentifikasi suara penelepon dengan tingkat akurasi $80 \%$ pada nilai ambang (threshold) 25.
\end{abstract}

Kata Kunci : Hotline, Speaker Recognition, Frekuensi, Mel-Frequency Cepstral Coefficient (MFCC), Vector Quantization (VQ)

\section{PENDAHULUAN}

Hotline merupakan saluran telepon untuk pelayanan masyarakat yang membutuhkan informasi berkaitan dengan institusi maupun perusahaan tertentu. Layanan hotline juga dapat meningkatkan kinerja dan mobilitas suatu institusi dengan menjadi media penghubung antara karyawan maupun departemen. Teknologi dan perangkat keras yang digunakan yaitu telepon yang terhubung dengan komputer, serta jaringan internet. Identifikasi penelepon dilakukan 
dengan menanyakan data diri penelepon, yang kemudian dicocokkan dengan database melalui komputer. Universitas Pembangunan Nasional "Veteran" Yogyakarta merupakan salah satu institusi yang menyediakan layanan hotline.

Hotline Universitas Pembangunan Nasional "Veteran" Yogyakarta dikelola oleh bagian Hubungan Masyarakat. Layanan tersebut merupakan layanan untuk umum, sehingga semua orang yang membutuhkan informasi mengenai kampus dapat mengaksesnya. Dalam meningkatkan mobilitas dari kegiatan kampus, staff maupun dosen memanfaatkan layanan tersebut untuk berbagai keperluan. Dosen beserta staff Universitas Pembangunan Nasional "Veteran" Yogyakarta yang berlokasi di kampus 2 Babarsari menggunakan layanan hotline untuk berkomunikasi dengan bagian-bagian yang berlokasi di rektorat kampus 1 Condongcatur. Penerapan teknologi serta sistem yang berjalan pada layanan hotline Universitas Pembangunan Nasional "Veteran" Yogyakarta memiliki beberapa kekurangan. Telepon yang digunakan untuk menerima panggilan tidak terhubung dengan komputer, sehingga tidak dilakukan pengecekan data penelepon dengan database. Identifikasi penelepon dilakukan dengan menanyakan nama, jabatan beserta asal jurusan atau bagian. Proses identifikasi tersebut beresiko terjadinya ketidaksesuaian data penelepon yang disampaikan dibandingkan dengan identitas sebenarnya penelepon. Informasiinformasi yang bersifat rahasia universitas dapat diketahui oleh masyarakat luas dengan menelepon bermodalkan nama, jabatan, beserta jurusan atau bagian salah seorang staff maupun dosen. Proses identifikasi penelepon dengan menanyakan identitas penelepon oleh petugas saat layanan hotline membuat durasi waktu telepon menjadi semakin lama. Semakin lama waktu telepon mengakibatkan biaya telepon yang dibebankan pada penelepon semakin besar.

Berdasarkan permasalahan tersebut diperlukan sebuah sistem hotline yang dapat mengidentifikasi identitas penelepon secara akurat dan dicocokkan dengan data yang terdapat pada database staff dan dosen Universitas Pembangunan Nasional "Veteran" Yogyakarta. Keakuratan identifikasi seseorang dapat dilakukan dengan mengenali ciri khas suaranya. Pengenalan suara saat ini dapat dipelajari dan dikenali melalui proses pembelajaran speaker recognition yang merupakan bagian dari voice recognition. Speaker recognition menangkap frekuensi dari suara seseorang, kemudian dibandingkan dengan frekuensi suara data latih yang ada. Frekuensi suara diekstraksi melalui metode Mel-Frequency Cepstral Coefficient (MFCC) sehingga menghasilkan informasi berdasarkan sinyal suara yang diucapkan. Informasi dalam bentuk Mel Frequency Cepstrum Coeficients dari semua data latih dosen beserta staff Universitas Pembangunan Nasional "Veteran" Yogyakarta kemudian diklasifikasikan dan dibandingkan dengan sinyal suara dari penelpon yang masuk melalui metode VQ (Vector Quantization). Proses klasifikasi, metode Algoritma LBG (Linde Buzo Gray) dipakai untuk membentuk codebook berdasarkan vektor ciri masing masing pengucap pada metode Vector Quantization

\section{TINJAUAN PUSTAKA}

\subsection{Speaker Recognition}

Identifikasi penutur (Speaker recognition) dapat didefinisikan sebagai proses memilih penutur (pembicara) yang mempunyai karakteristik ciri suara yang mendekati sama dengan suara masukan. Bermacam-macam bunyi ucapan (fonem) yang berbeda merupakan cara yang paling mudah untuk membedakan antara pengucap yang satu dengan yang lain. Fonem yang berbeda tersebut antara lain vokal, diphthong, semivokal, unvoiced fricative, voiced fricative, voice dan unvoiced stop (Apriyono, Wahyudi, \& Hidayatno, 2011). Dalam hal ini dapat diimplementasikan untuk autentifikasi dengan menggunakan password, no kartu, kode PIN dan lainnya yang dapat memberikan hak akses ke suatu sistem bilamana suara pembicara diterima dengan teks yang sama (Prasetyawan, 2016).

\subsection{Mel-Frequency Cepstral Coefficient}

Ekstrasi ciri sinyal suara menggunakan MFCC didasarkan atas variasi bandwith terhadap frekuensi pada telinga manusia yang merupakan filter, yang bekerja secara linier pada frekuensi rendah dan bekerja secara logaritmik pada frekuensi tinggi. metode MFCC merupakan metode yang paling sering digunakan dalam melakukan ekstraksi fitur suara dalam penelitian pengenalan identitas pembicara dan pengenalan perintah suara, karena mampu untuk mengekstraksi karakteristik sinyal suara secara jelas, yang relatif berbeda dari sifat saluran suara pembicara 
dan lebih efektif digunakan untuk pengenalan suara yang mengandung noise Djamal, \& Yuniarti, 2017). Diagram proses MFCC dapat dilihat pada Gambar 1.

(Munggaran,

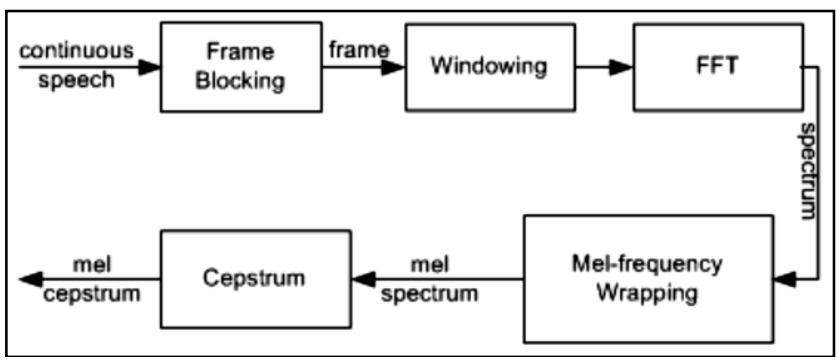

Gambar 1. Diagram proses MFCC

Frame Blocking merupakan proses pembagian suara menjadi beberapa frame dan satu frame terdiri dari beberapa sampel. Proses ini diperlukan untuk membentuk sinyal suara yang nonstationary menjadi sinyal suara yang quasi-stationary sehingga dapat diubah dari domain waktu ke domain frekuensi dengan transformasi Fourier. Langkah selanjutnya adalah windowing setiap frame. Hal ini dilakukan untuk meminimalisasi diskontinuitas sinyal pada permulaan dan akhir setiap frame. Konsepnya adalah meruncingkan sinyal ke angka nol pada permulaan dan akhir setiap frame. Ada banyak fungsi window, namun yang sering digunakan dalam Speaker identification adalah Hamming window. Fungsi window ini menghasilkan sidelobe level yang tidak terlalu tinggi (kurang lebih $-43 \mathrm{~dB}$ ), selain itu noise yang dihasilkan pun tidak terlalu besar. Pengolahan selanjutnya menggunakan Fast Fourier Transform (FFT), yang mengubah setiap frame $\mathrm{N}$ sampel dari domain waktu ke domain frekuensi. FFT adalah algoritma cepat untuk menerapkan Descrete Fourier Transform (DFT) yang didefinisikan pada set $\mathrm{N}$ sampel xn, sebagai berikut:

$$
X_{k}=\sum_{n=0}^{N-1} x_{n} e^{\frac{-2 j \pi k n}{N}}, k=0,1,2, \ldots N-1
$$

Dalam mel-frequency wrapping, sinyal hasil FFT dikelompokkan ke dalam berkas filter triangular ini. Maksud pengelompokkan ini adalah setiap nilai FFT dikalikan terhadap gain filter yang bersesuaian dan hasilnya dijumlahkan. Langkah terakhir dalam proses MFCC ini mengubah spektrum log mel kembali ke waktu. Hasilnya disebut MFCC (Mel Frequency Cepstrum Coeficients). Cepstrum adalah sebutan kebalikan untuk spectrum. Cepstrum biasa digunakan untuk mendapatkan informasi dari suatu sinyal suara yang diucapkan oleh manusia. Karena koefisien spektrum mel adalah bilangan real, maka konversinya ke domain waktu menggunakan Discrete Cosine Transform (DCT). Formula untuk menghitung koefisien MFCC itu adalah:

$$
C_{n}=\sum_{k=1}^{K}\left(\log S_{k}\right) \cos \left[\frac{n\left(k-\frac{1}{2}\right) \pi}{K}\right] \ldots
$$

dengan $S k$ merupakan keluaran dari proses filterbank dan jumlah koefisien yang diharapkan (Prasetyawan, 2016).

\subsection{Metode Virtual Quantization}

Hasil ekstraksi MFCC (koefisien MFCC) untuk basisdata kemudian dibuat codebook-nya dengan menggunakan metode $\mathrm{VQ}$. dengan menggunakan metode $\mathrm{VQ}$ diperoleh codebook yang isinya merepresentasikan koefisien MFCC yang telah diperoleh, yang berisi tentang informasi karakteristik dari masing-masing pengucap (Apriyono et al., 2011). Vector Quantitation (VQ) merupakan teknik dalam membangun ciri pencocokan (feature matching) pada speaker identification. Keuntungan dari menggunakan VQ adalah sederhana, mudah diimplementasikan dan akurasi tinggi. VQ adalah proses mapping vektor dari ruang vektor yang luas menjadi sejumlah daerah terhingga di ruangan itu. Kumpulan codeword disebut codebook. Jarak dari vektor akustik ke codeword terdekat pada codebook disebut VQdistortion. Diagram yang menggambarkan ciri pencocokan dengan vektor kuantisasi dapat dilihat pada Gambar 2. 


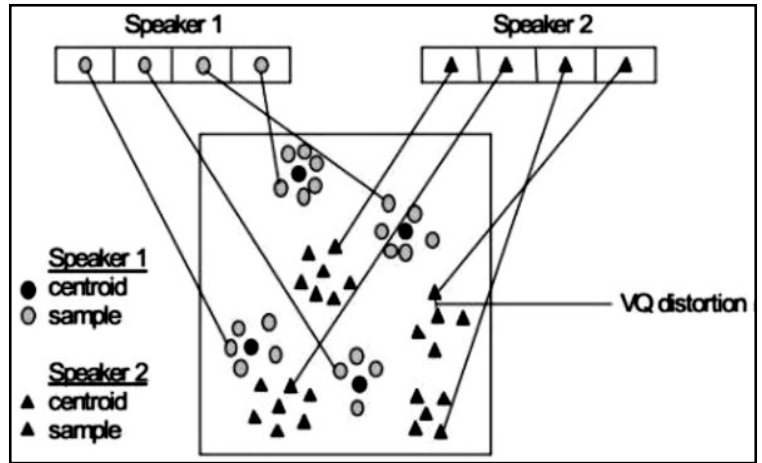

Gambar 2. Konseptual vektor kuantisasi

Perhitungan VQ-distortion menggunakan Euclidean distance. Pada pengenalan pengucap dengan menggunakan metode $V Q$, jarak penyimpangan Euclidean ini digunakan untuk menghitung jarak penyimpangan antara masing-masing vektor ciri dengan codeword pada tiaptiap codebook, sehingga dapat diketahui codeword mana yang memiliki jarak penyimpangan terdekat dengan vektor ciri (Apriyono et al., 2011). distorsi diukur berdasarkan minimisasi jarak Euclidean yang digunakan saat mencocokkan (matching) penutur tak dikenal dengan database penutur (Mustofa, 2008). Formula euclidean distance dituliskan sebagai berikut :

dengan:

$$
D_{i}=\sqrt{\sum_{i=0}^{N}\left(x_{1}-x_{2}\right)^{2}}
$$

$D i=$ jarak terhadap tekstur i yang terkecil pada

$x 1=$ ciri dari tekstur yang diklasifikasikan

$x 2=$ ciri dari tekstur

Tekstur akan diklasifikasikan sebagai tekstur $i$ apabila Di merupakan jarak terkecil dibandingkan dengan jarak yang lainnya. Algoritma yang terkenal untuk membangun VQcodebook, yaitu algoritma LBG. Algoritma tersebut dilaksanakan oleh prosedur rekrusif dengan langkah berikut ini:

1. Desain sebuah codebook vektor-1, yang merupakan centroid dari seluruh himpunan vektor training (tidak ada iterasi yang diperlukan disini).

2. Gandakan ukuran codebook dengan memisahkan setiap current codebook yn sesuai dengan aturan.

$$
\begin{aligned}
& y_{n}^{+}=y_{n}(1+\varepsilon) . \\
& y_{n}^{-}=y_{n}(1-\varepsilon) .
\end{aligned}
$$

dengan $\mathrm{n}$ bervariasi dari 1 sampai ukuran current codebook dan adalah parameter pemisahan $(=0,01)$.

3. Nearest-Neighbor Search: untuk setiap vektor training, temukan codeword pada codebook saat yang jaraknya terdekat (dalam hal pengukuran kesamaan) dan menetapkan vektor tersebut ke cell yang sesuai (terkait dengan codeword terdekat).

4. Perbarui centroid, memperbarui codeword dalam setiap cell menggunakan centroid dari vektor training yang ditetapkan ke cell tersebut.

5. Iterasi 1: ulangi langkah 3 dan 4 sampai jarak (distance) rata-rata turun dibawah ambang (preset threshold).

6. Iterasi 2: ulangi langkah 2, 3 dan 4 sampai ukuran codebook dirancang (Prasetyawan, 2016).

\section{METODOLOGI PENELITIAN DAN PENGEMBANGAN SISTEM}

Metodologi penelitian yang digunakan adalah metode penelitian kuantitatif. Metode penelitaian kuantitatif diterapkan untuk menjawab pertanyaan penelitian berdasarkan variabel yang bisa diukur dengan angka. Variabel pada penelitian ini adalah suara penutur yang diidentifikasi dan diukur berdasarkan nilai dari masing-masing data. Metode penelitian kuantitatif menarik kesimpulan dimulai dari teori-teori yang ada sebelumnya untuk kemudian diuji dengan data di 
lapangan. Data-data diperoleh dari proses pengumpulan data yang terdiri dari studi pustaka, observasi, dan wawancara. Metodologi pengembangan sistem yang digunakan untuk membangun sistem ini adalah Guidelines for Rappid Application Engineering (GRAPPLE). GRAPPLE merupakan metodologi yang fleksibel dan memberikan panduan yang jelas dalam proses pengembangan sistem Proses dimulai dari tahapan requirement gathering, analysis, design, development, dan deployment (Schmuller, 2004). Kerangka kerja penelitian digambarkan pada gambar 4 .

\subsection{Perancangan (Design)}

Aplikasi pengenalan penutur teridiri dari beberapa design (rancangan). Rancangan dibentuk berdasarkan analisa sistem yang akan dibangun. Perancangan meliputi arsitektur sistem, unified modeling diagram dan diagram alir (flowchart).

\subsection{Arsitektur Sistem}

Proses pengenalan suara dibagi menjadi dua proses perekaman. Proses perekaman pertama dilakukan pada pegawai selaku data latih. Perekaman kedua dilakukan pada penelepon yang masuk saat layanan hotline. Pada perekaman suara data latih, pegawai menginput suara pada telepon landline dalam kondisi tidak ada telepon masuk maupun keluar. Data audio dari telepon kemudian dialirkan ke telephone adapter box melalui kabel RJ-11. Data audio yang diterima kemudian diteruskan ke komputer melalui kabel audio yang dihubungkan dengan kabel audio splitter. Data audio yang diterima lalu direkam oleh aplikasi dan menghasilkan file audio latih dengan format wav. Lokasi dari file kemudian disimpan ke dalam database, sedangkan data audio dari file data latih di ekstraksi oleh metode MFCC untuk menghasilkan nilai koeffisien MFCC. Nilai koeffisien MFCC lalu diproses oleh metode VQ untuk membentuk codebook data latih. Pada perekaman suara penelepon, data audio dari telepon kemudian dialirkan ke telephone adapter box melalui kabel RJ-11. Data audio yang diterima kemudian diteruskan ke komputer melalui kabel audio yang dihubungkan dengan kabel audio splitter. Data audio yang diterima lalu direkam oleh aplikasi dan menghasilkan file audio dengan format .wav. Data audio dari file di ekstraksi oleh metode MFCC untuk menghasilkan nilai koeffisien MFCC. Nilai koeffisien MFCC dari suara penelepon serta codebook data latoh kemudian diproses oleh Euclidean Distance untuk pengenalan suara penelepon. Setelah dikenali, aplikasi meminta data pegawai yang dikenali kepada database. Data pegawai kemudian ditampilkan kepada admin melalui aplikasi. Arsitektur sistem digambarkan pada Gambar 3.

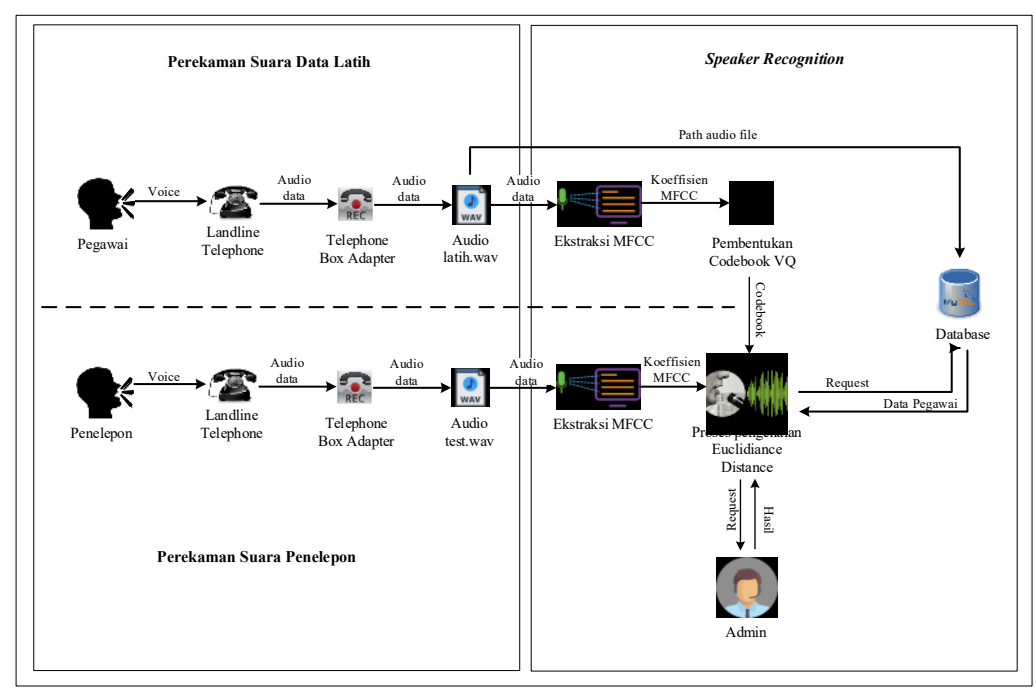

Gambar 3. Arsitektur Sistem

\section{UML (Unified Modeling Language)}

$U M L$ dapat dibuat model untuk semua jenis aplikasi perangkat lunak, dimana aplikasi tersebut dapat berjalan pada perangkat keras, sistem operasi dan jaringan apapun, serta ditulis dalam program apapun (Sulistyorini, 2009). UML berfungsi untuk memodelkan sistem pada aplikasi pengenalan penutur. UML membantu dalam memvisualisasikan serta mendokumentasikan 
sistem yang dibuat pada penelitian ini. Pemodelan UML pada penelitian ini terdiri dari use case diagram, class diagram, activity diagram, dan sequence diagram.

a. Use Case Diagram

Use case diagram menggambarkan interaksi antara admin selaku aktor beserta use case dari aplikasi pengenalan suara. Use case menggambarkan fungsi dari setiap antarmuka pada aplikasi. Use case diagram dimodelkan pada tahapan analisis, dimana fungsi dari sistem dimodelkan dengan use case. Relasi include menjelaskan kepemilikan sebuah use case atas use case lain dari sistem. Use case pengenal penutur merupakan fungsi utama sistem. Use case pengenal penutur berisi fungsi dalam pengenalan penutur pada layanan hotline. Use case lihat memfasilitasi aktor untuk dapat melihat data pegawai yang terdaftar pada aplikasi pengenalan penutur. Pada tampilan data pegawai admin dapat berinteraksi dengan dua use case lain yaitu use case tambah data pegawai beserta ubah data pegawai. Admin dapat mengelola data suara melalui use case lihat data suara. Data penelepon yang telah diidentifikasi oleh aplikasi dapat dilihat melaului use case lihat penelepon dikenal. Use case digambarkan pada Gambar 4.

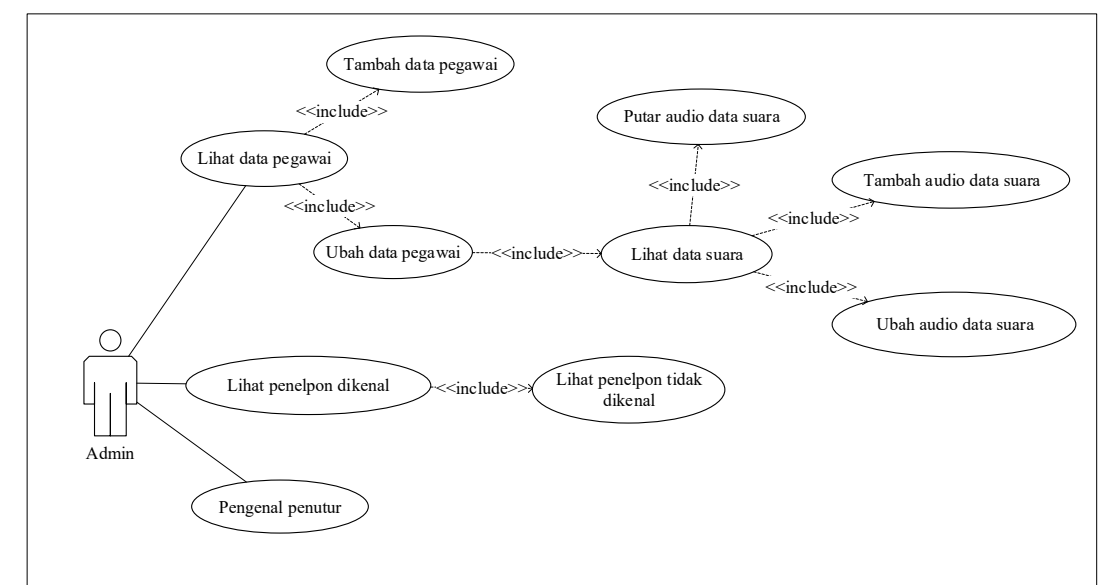

Gambar 4. Use Case Diagram

b. Class Diagram

Class diagram memodelkan hubungan antara semua class pada sistem. Masing masingmasing class memliki method dan atribut. Class diagram merupakan pemodelan berorientasi objek pada tahapan analisa. Class diagram menggambarkan perintah-perintah yang harus dikerjakan sesuai dengan informasi yang didapatkan pada tahapan requirement gathering. Terdapat tujuh class utama pada sistem, setiap class merupakan antarmuka aplikasi pada sistem. Diantara ketujuh class tersebut tidak terdapat interaksi, karena setiap fungsi yang dibutuhkan telah dideklarasikan pasa setiap class. Penggunaan PYQT4 sebagai GUI berpengaruh pada pemodelan class diagram, dimana ketujuh class utama terhubung ke class PyQT4 yang mereferensikan semua variabel beserta fungsi dalam menampilkan antarmuka.

c. Activity Diagram Pengenalan Penutur

Activity diagram pengenal penutur merupakan antarmuka yang berfungsi dalam pengidentifikasian penelepon masuk. Setelah tampilan awal aplikasi ditampilkan, kemudian user memilih menu recognizer hotline. Sebelum sistem menampilkan antarmuka pengenalan penutur, sistem melakukan training codebook data latih. Nilai codebook kemudian disimpan kedalam file penyimpanan $\mathrm{xml}$. Sistem kemudian menampilkan antarmuka pengenalan penutur. Pada antarmuka pengenalan penutur, apabila terdapat telepon masuk, user dapat menekan tombol mulai untuk memulai mengenali suara penelepon. Sistem kemudian melakukan proses perekaman suara penelepon. Proses perekaman diawali dengan dipanggilnya fungsi timer. Melalui fungsi timer, diatur interval perekaman suara penelepon. Setelah timer dimulai, sistem mengambil nilai codebook data latih dari file penyimpanan $\mathrm{xml}$. Audio suara rekaman tersebut kemudian diekstraksi untuk kemudian diubah menjadi koefisien MFCC. Proses ekstraksi data duara menggunakan metode MFCC. Koefisien MFCC lalu dibandingakan dengan nilai codebook data latih sehingga menghasilkan nilai yang 
menunjukkan urutan file suara. Apabila file suara dikenal maka sistem akan menampilkan data penelepon dikneal dengan mengambil data pegawai dari server. Apabila penelepon tidak dikenali maka sistem akan menampilkan tulisan "Tidak Dikenal" pada semua label form tampilan pengenal suara. Tombol berhenti berfungsi untuk menghetikan proses identifikasi penelepon, apabila kegiatan telepon telah berakhir. Activity diagram digambarkan pada Gambar 5.

d. Sequence Diagram Pengenalan Penutur

Sequence diagram pengenalan penutur pada Gambar 6 menggambarkan interaksi pengiriman pesan antara objek-objek yang berperan dalam fungsi pengenalan penutur berdasarkan waktu. Selain user terdapat delapan objek pada sequence diagram pengenalan penutur. Ui pengenalan penutur merepresentasikan class antarmuka pengenalan penutur. User mengawali proses dengan mengirim pesan akses kepada Ui pengenal penutur.

Ui pengenal penutur kemudian mengembalikan pesan tersebut dengan menampilkan antarmuka pengenalan penutur. Kemudian user mengirim pesan kepada antarmuka untuk memulai rekam suara pada microphone. Berdasarkan pesan tersebut kemudian antarmuka memulai timer dengan interval 500 milidetik. Pada proses perekaman, antarmuka meminta sinyal audio dari telepon adapter yang bertindak sebagai masukan microphone. Pesan yang diterima kemudian diteruskan ke telepon yang terhubung dengan adapter. Telepon kemudian mengembalikan pesan pesan ke adapter berupa data audio penelepon. Data audio penelepon masuk kemudian diteruskan oleh adapter ke antarmuka. Data tersebut kemudian direkam oleh class ui pengenalan suara selama 4 detik. Setelah proses perekaman selsesai, antarmuka kemudian mengirim pesan ke folder test untuk menyimpan file audio yang dihasilkan dan berformat .wav. Setelah file suara berhasil tersimpan pada storage. Antarmuka mengirim pesan kepada fungsi training untuk menghasilkan nilai codebook mfcc dengan masukan berupa nfiltbank. Setelah diproses, kemudian fungsi training mengembalikan nilai codebook mfcc ke antarmuka. Langkah selanjutnya, antarmuka mengirim pesan untuk membaca file suara penelepon yang terekam pada folder test. Nilai yang diterima dari pembacaan file audio adalah $f s$ dan $s$. Setelah mendapatkan nilai $f s$ dan $s$, antarmuka menirim pesan kepada fungsi MFCC untuk memproses $f s, s$, dan nfiltbank menjadi mel_coeff. Setelah diproses kemudian MFCC mengembalikan nilai mel_coeff kepada antarmuka. Selanjutnya antarmuka mengirim pesan kepada fungsi minDistance untuk memproses nilai mel_coeff dan codebook_mfcc menjadi $s p \_m f c c$. Setelah diproses kemudian fungsi minDistance mengembalikan nilai $s p \_m f c c$. 


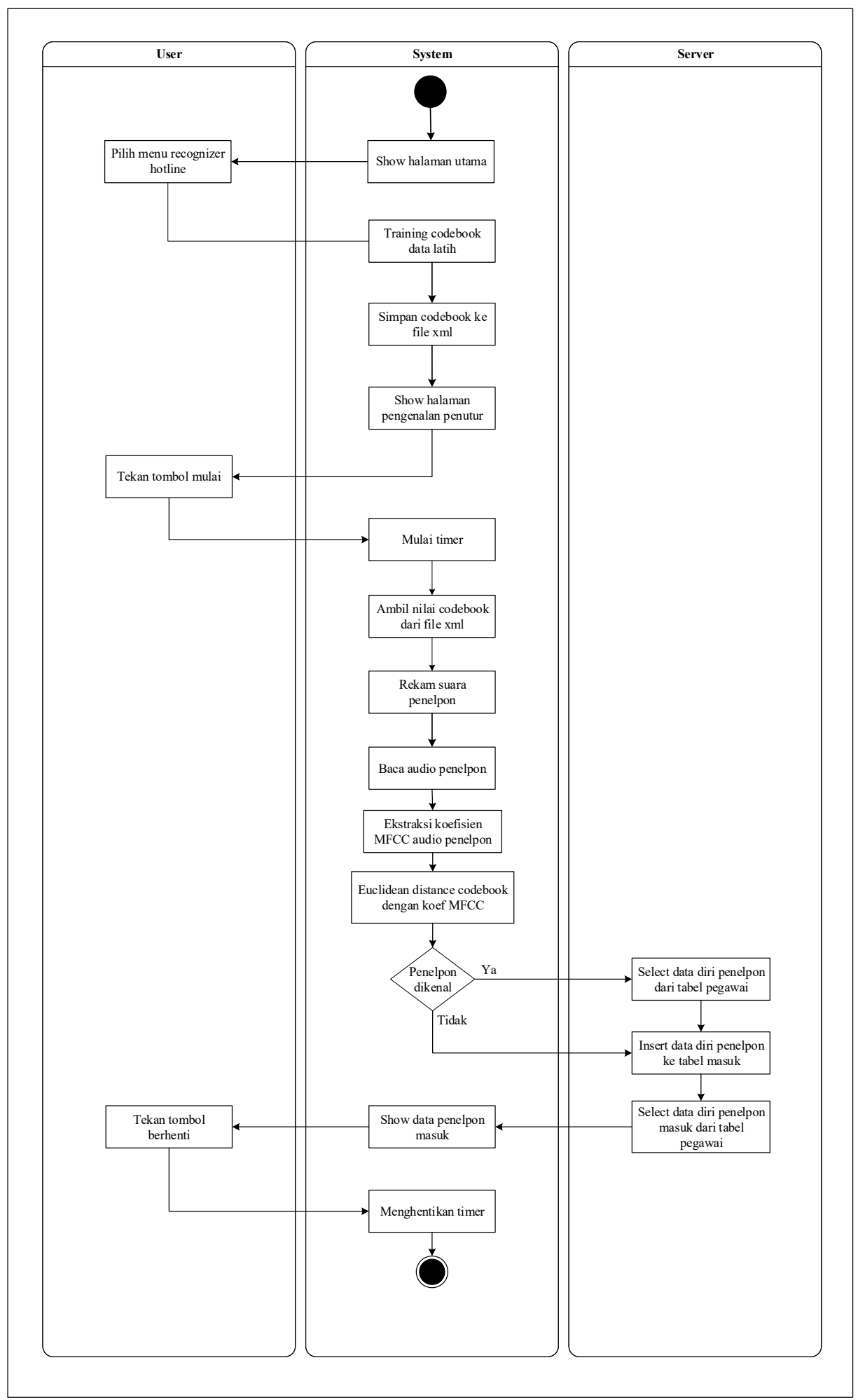

Gambar 5. Activity Diagram Pengenalan Penutur 


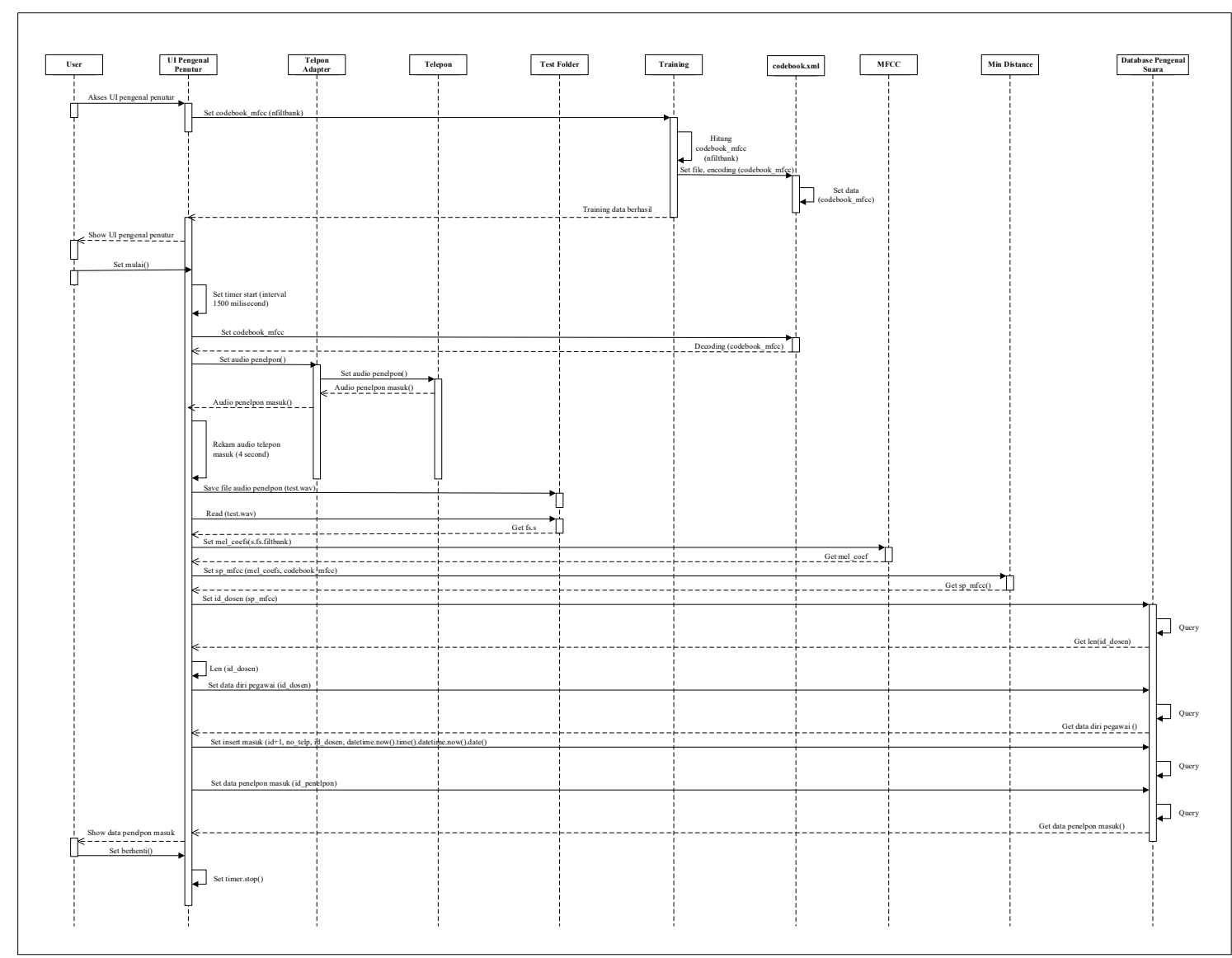

Gambar 6. Sequence Diagram Pengenalan Penutur

\subsection{Flowchart}

Flowchart menggambarkan urutan proses secara mendetail dan hubungan antara suatu proses (instruksi) dengan proses lainnya dalam program. Flowchart pada penelitian ini terdiri dari proses pengenalan penutur, training data latih, ekstraksi fitur, metode Vector Quantization, serta Minimum Distance.

a. Flowchart Pengenalan Penutur

Pengenalan penutur merupakan proses pengidentifikasian suara penelepon yang masuk untuk ditampilkan pada aplikasi. Admin selaku pengguna aplikasi dapat melihat identitas penelepon tanpa harus menanyakannya secara langsung. Pengenalan penutur dijelaskan pada flowchart dimulai dengan mencari nilai codebook. Nilai codebook yang disimpan oleh prosedur training data latih pada file $\mathrm{xm} /$ kemudian diambil melalui mekanisme decoding. File audio penelepon kemudian diproses oleh prosedur ekstraksi MFCC untuk dihasilkan nilai mel koeffisien. Nilai koeffisien data suara penelepon dibandingkan dengan codebook data latih melalui prosedur minDistance untuk menghasilkan nilai $s p \_m f c c$. Nilai $s p \_m f c c$ merepresentasikan urutan file suara data latih yang memiliki selisih koeffisien terdekat dengan suara penelepon masuk. Kemudian diberikan kondisi apabilai nilai $s p \_m f c c$ lebih besar sama dengan 1, maka aplikasi akan mengambil data pegawai dengan id sama dengan nilai sp_mfcc. Flowchart pengenalan penutur digambarkan pada gambar 7 . 


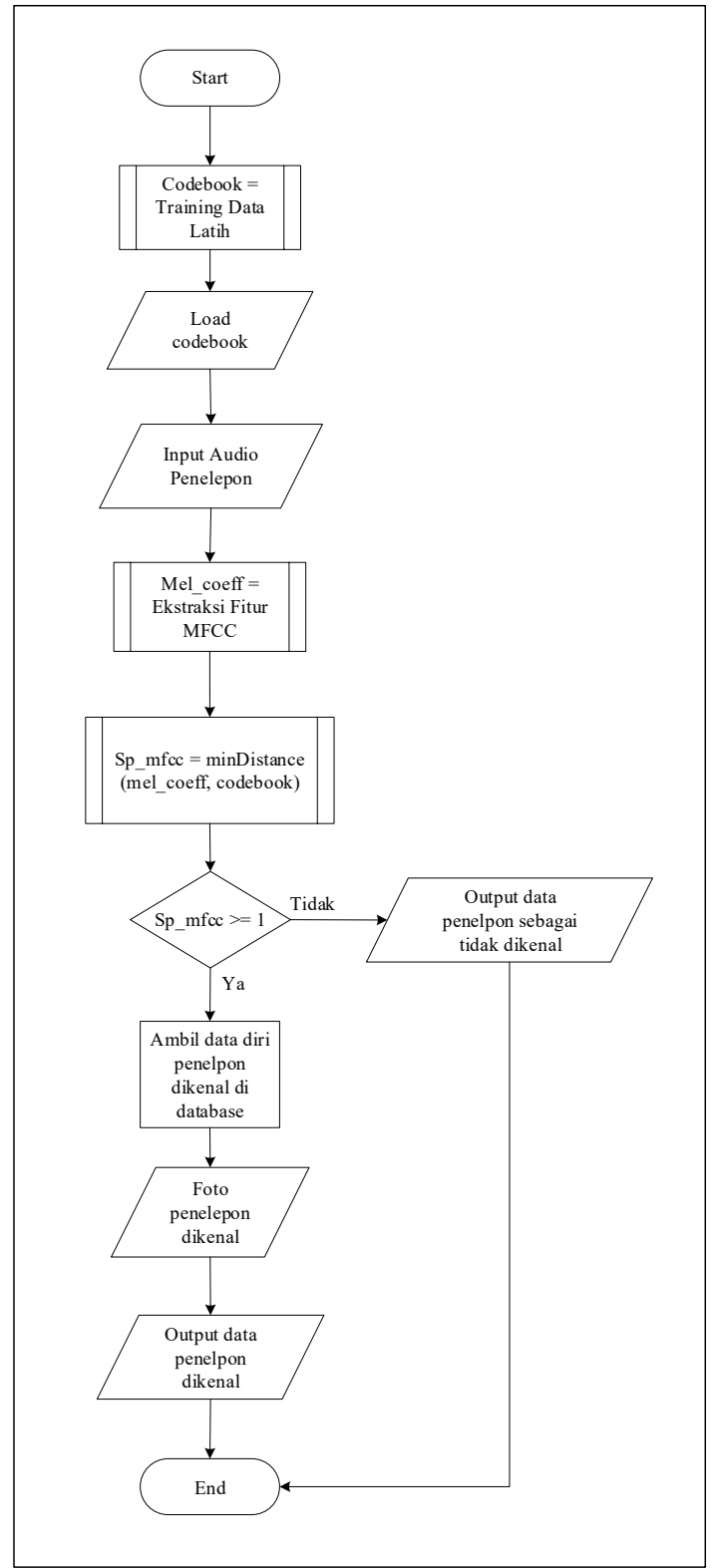

Gambar 7. Flowchart Pengenalan Penutur

b. Flowchart Training Data Latih

Training data latih merupakan proses penjabaran dari prosedur pencarian codebook pada flowchart pengenalan penutur. Proses dimulai dengan membaca input file suara latih pegawai yang terdapat pada storage folder train. Folder yang dibaca kemudian ekstraksi oleh prosedur ekstraksi fitur MFCC, untuk menghasilkan nilai mel_coeff. Nilai mel_coeff kemudian menjadi masukan untuk prosedur pada proses selanjutnya yaitu pembuata codebook pada metode $V Q$. Proses pembacaan file hingga prosedur VQ dilakukan secara berulang sesuai dengan jumlah file suara data latih. Nilai codebook dari semua data latih suara lalu disimpan kedalam file penyimpanan dengan format $\mathrm{xml}$. Penyimpanan dilakukan melalui tahapan encoding data terlebih dahulu. Flowchart digambarkan pada Gambar 8. 


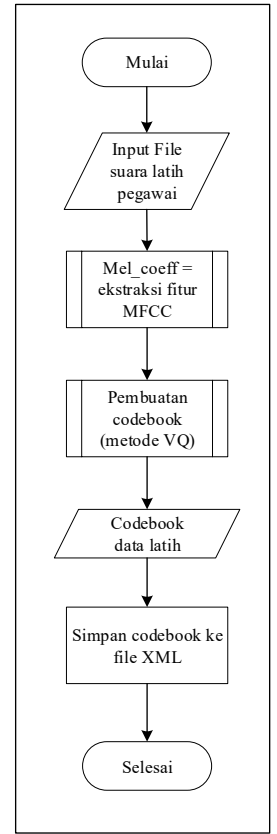

Gambar 8. Flowchart Training Data Latih

c. Flowchart Ekstraksi Fitur

Proses ekstraksi fitur merupakan proses ekstraksi data audio dari file suara yang masuk, untuk dihasilkan nilai koeffisien. Proses dimulai dengan membaca file suara latih pegawai pada storage. Proses MFCC ini mengubah spektrum log mel kembali ke waktu sehingga menghasilkan MFCC (Mel Frequency Cepstrum Coeficients. Flowchart digambarkan pada Gambar 9.

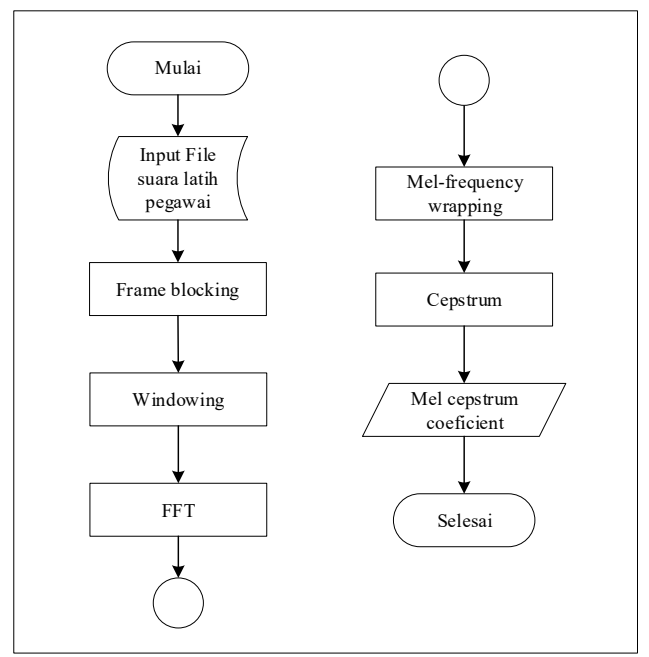

Gambar 9. Flowchart Ekstraksi Fitur

d. Flowchart Metode Vector Quantization

Flowchart metode vector quantization merupakan prosedur yang terdapat pada proses training data latih. Proses pada metode ini dimaksudkan untuk membentuk codebook dari setiap data latih. Nilai codebook yang dihasilkan merupakan nilai dari masing- masing data suara yang masuk dan akan diproses oleh proses data training. Flowchart digambarkan pada Gambar 10. 


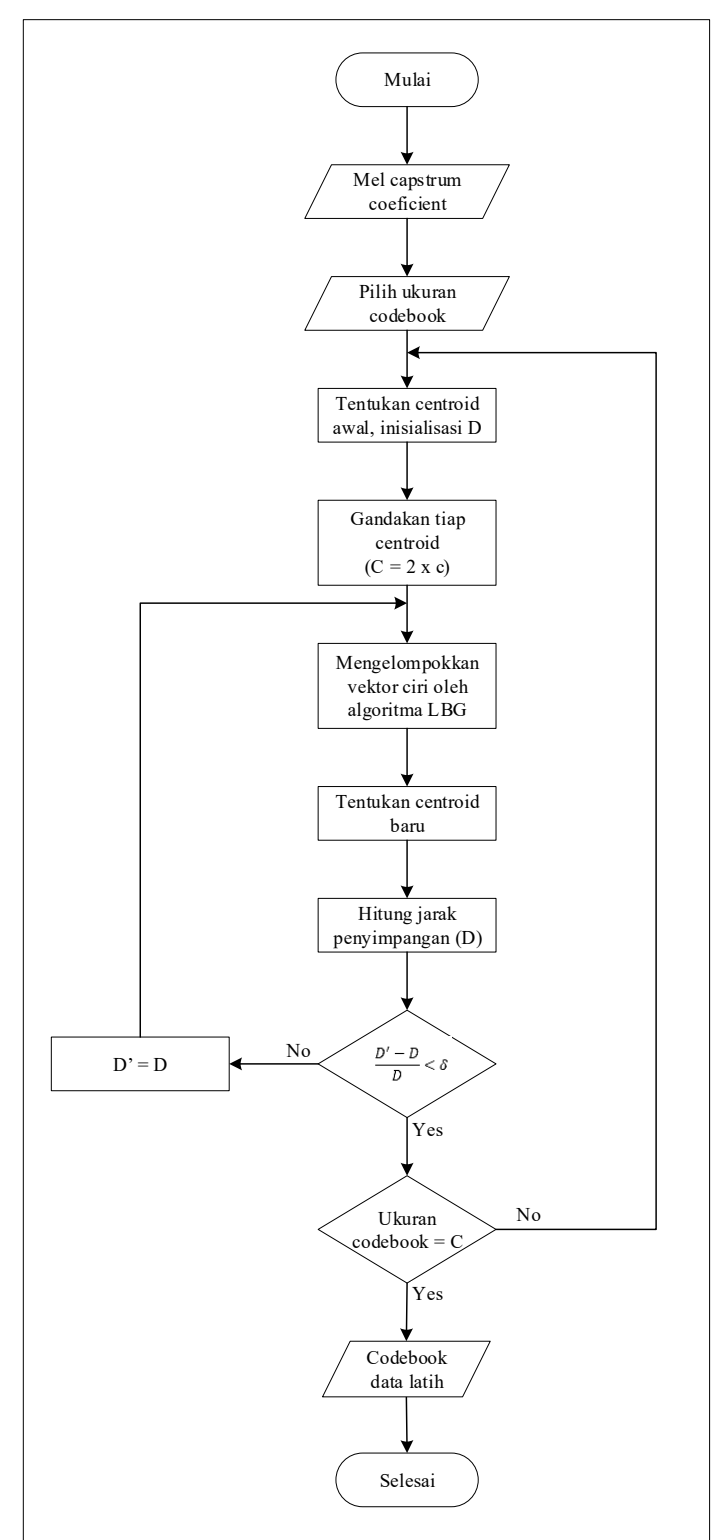

Gambar 10. Flowchart Metode Vector Quantization

e. Flowchart Minimum Distance

Minimum distance dimulai dengan membaca nilai mel_coeff penelepon masuk serta codebook data latih. Kemudian dideklarasikan variabel $\mathrm{n}$ sebagai jumlah kolom dari array mel_coeff, serta $\mathrm{p}$ merupakan jumlah kolom array codebook. Kemudian pada kondisi apabila nilai $\bar{n}$ lebih kecil dari $\mathrm{p}$, maka nilai $\mathrm{D}$ ditentukan dengan transpose mel coeff lalu diproses dengan codebook untuk menghasilkan nilai $\mathrm{D}$. Apabila tidak memenuhi kondisi maka nilai dari codebook yang akan di tranpose lalu diproses uuntuk meghasilkan nilai D. Nilai Dist merupakan penjumlahan nilai minimum $D$ dibagi dengan jumlah baris pada $D$. Apabila nilai Dist yang dihasilkan lebih kecil dari distmin, maka akan menghasilkan keluara nilai $s p \_m f c c$. Flowchart digambarkan pada Gambar 11. 


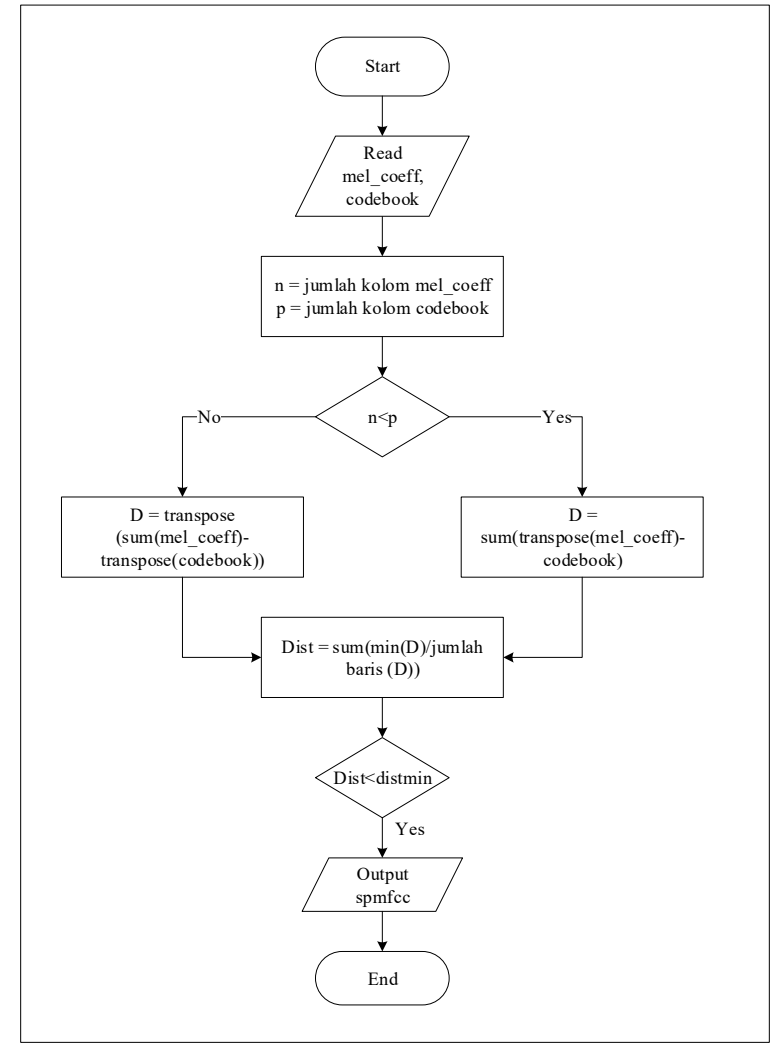

Gambar 11. Flowchart Minimum Distance

\section{HASIL DAN PEMBAHASAN}

\subsection{Halaman Utama}

Halaman utama merupakan antarmuka awal dari aplikasi. User dapat mengakses antarmuka lain melalui menu-menu pada menu bar. Terdapat tiga menu pada menu bar, yaitu : home, database, dan recognizer. Menu home mengarahkan aplikasi ke antarmuka utama. Menu database terdiri dari submenu dosen dan penelpon. Submenu dosen mengarahkan aplikasi ke antarmuka database pegawai. Submenu penelpon mengarahkan aplikasi ke antarmuka data penelpon dikenal. Menu recognizer terdiri dari submenu hotline yang mengarahkan aplikasi ke antarmuka pengenalan penutur. Antarmuka utama juga menampilkan judul aplikasi serta waktu dan tanggal saat ini. Antarmuka halaman utama dapat dilihat pada Gambar 12.

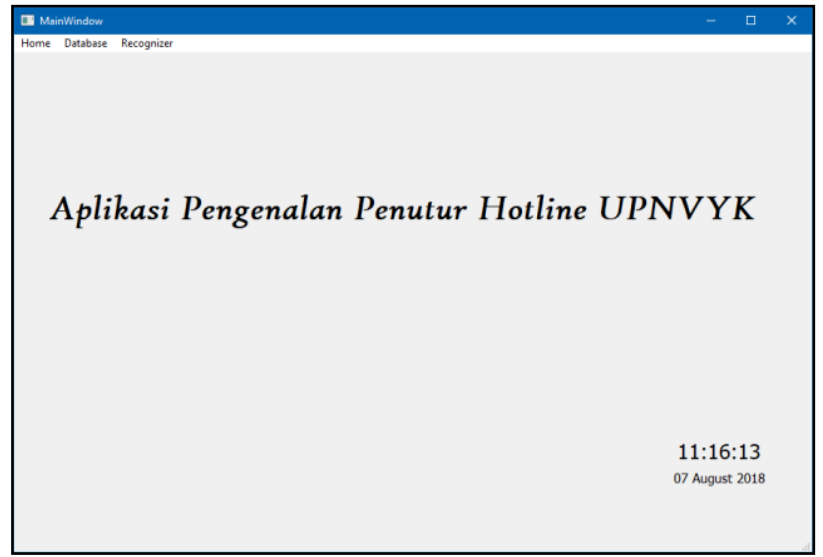

Gambar 12. Halaman Utama 


\subsection{Halaman Pengenalan Penutur}

Halaman pengenalan penutur merupakan halaman yang digunakan untuk melakukakan pengidentifikasian suara penelepon. Terdapat tiga menu pada Terdapat tiga menu pada menu bar, yaitu home, database, dan recognizer. Proses pengidentifikasian suara penelepon dimulai ketika user menekan tombol mulai. Setelah tombol mulai ditekan, aplikasi akan mulai merekam suara. Hasil rekaman suara tersebut kemudian dibadingkan dengan data suara latih pegawai. Apabila suara penelepon masuk memiliki nilai yang mendekati salah satu dari data suara latih pegawai, maka aplikasi akan menampilkan data pegawai. Data pegawai yang ditampilkan diambil dari database pegawai yang terdiri dari nama, NIK/NIP, no telepon, jabatan, jurusan, fakultas, serta foto. Data pegawai ditampilkan melalui label-label yang disediakan pada antarmuka halaman pengenalan penutur. Apabila suara penelepon tidak teridentifikasi sebagai pegawai, maka halaman pengenalan penutur akan menampilkan tulisan "Tidak Dikenal" pada semua label, serta mengosongkan label foto. Aplikasi akan menampilkan hasil identifikasi suara setiap 3 sampai 4 detik. Tombol berhenti berfungsi untuk menghentikan aplikasi dalam mengidentifikasi sauara penelepon. Waktu beserta tanggal saat ini ditampilkan melalui label yang terletak pada bawah label foto. Antarmuka halaman pengenalan penutur dapat dilihat pada Gambar 13.

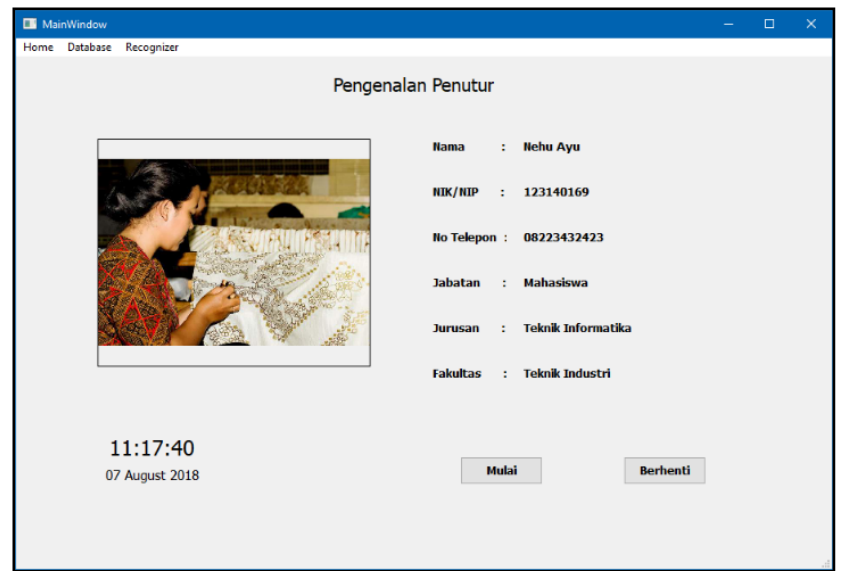

Gambar 13. Halaman Pengenalan Penutur

\subsection{Halaman Data Penelepon Dikenal}

Halaman data penelepon dikenal merupakan halaman yang digunakan untuk menampilkan data penelepon masuk yang dikenal sebagai pegawai yang terdaftar pada basis data. User dapat mengakses halaman data penelepon dikenal dengan menekan action penelepon pada menu database. Menu bar terdiri dari home, database, dan recognizer. Judul dari halaman terletak pada bagian atas tabel. Semua data penelepon yang dikenali oleh aplikasi ditampilkan pada tabel. Kolom pada tabel terdiri dari id, status, nama, jurusan, jabatan, no telepon, waktu, dan tanggal. Jumlah penelepon dikenali ditampilkan pada label yang terletak pada bagian kiri atas dari tabel. Pada bagian kanan atas tabel terdapat tombol bertuliskan tidak dikenal yang berfungsi untuk menampilkan antarmuka tampil data penelepon tidak dikenal. Antarmuka halaman data penelepon dikenal dapat dilihat pada Gambar 14 


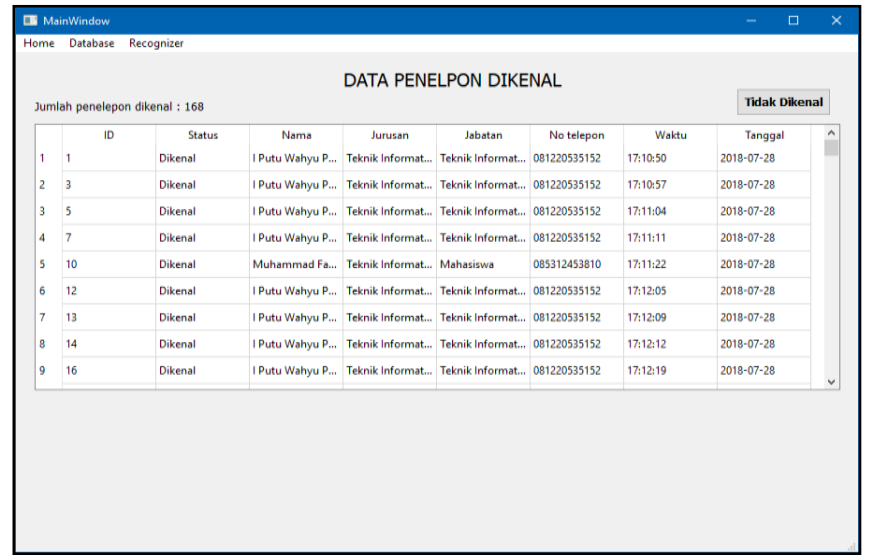

Gambar 14. Halaman Data Penelepon Dikenal

\subsection{Halaman Data Penelepon Tidak Dikenal}

Halaman data penelepon tidak dikenal merupakan halaman yang digunakan untuk menampilkan data penelepon masuk yang dikenal sebagai pegawai yang terdaftar pada basis data. User dapat mengakses halaman data penelepon dikenal dengan menekan tombol "Tidak Dikenal" pada halaman data penelepon dikenal. Menu bar terdiri dari home, database, dan recognizer. Judul dari antarmuka terletak pada bagian atas tabel. Semua data penelepon yang dikenali oleh aplikasi ditampilkan pada tabel. Kolom pada tabel terdiri dari id, status, nama, jurusan, jabatan, no telepon, waktu, dan tanggal. Jumlah penelepon tidak dikenali ditampilkan pada label yang terletak pada bagian kanan dari tabel. Pada bagian bawah jumlah penelepon tidak dikenal terdapat tombol bertuliskan kembali yang berfungsi untuk mengembalikan aplikasi ke halaman tampil penelepon dikenal. Antarmuka halaman data penelepon tidak dikenal dapat dilihat pada Gambar 15.

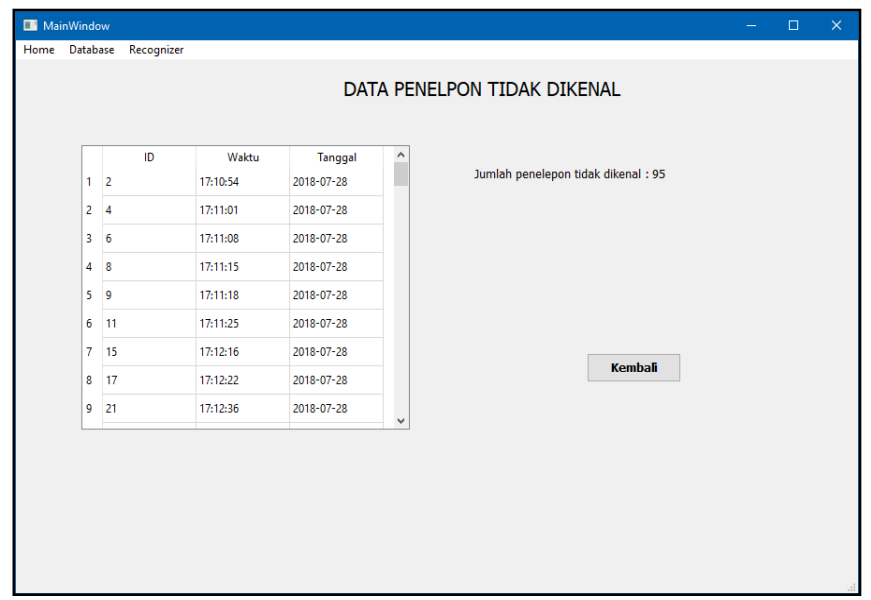

Gambar 15. Halaman Data Penelepon Tidak Dikenal

\subsection{Pengujian Sistem}

Pengujian sistem berfungsi untuk mendapatkan nilai ambang (threshold) yang tepat serta menghitung akurasi aplikasi pengenalan penutur. FAR dan $F R R$ mengukur kesalahan keputusan untuk keseluruhan sistem. Pengukuran ini menggabungkan tingkat kesalahan pencocokan, dan kegagalan untuk memperoleh nilai sesuai dengan kebijakan keputusan sistem (Mansfield, Kelly, Chandler, \& Kane, 2001). Pengujian dilakukan dengan delapan nilai threshold yang berbeda. Pengujian ini dibagi menjadi dua bagian. Pengujian pertama merupakan nilai ambang, dan pengujian kedua adalah pengujian akurasi. Jumlah orang yang diuji pada kedua pengujian tersebut berbeda.

a. Pengujian Nilai Ambang (Treshold)

Pengujian nilai ambang dilakukan dengan menguji masing-masing seputuh suara dari dua orang yang berbeda. Orang pertama telah terdaftar sebagai data training pada aplikasi. Nilai suara latih dari orang pertama disimpan dalam file codebook yang berformat $x \mathrm{ml}$. Orang kedua 
merupakan orang yang tidak terdaftar pada aplikasi. Pada orang yang terdaftar sebagai data training, pengujian yang dilakukan adalah $F R R$. Orang yang dijadikan objek pengujian $F R R$ adalah Wahyu patrika. Data suara uji diambil berdasarkan suara yang direkam pada saat objek melakukan telepon dan terhubung ke aplikasi pengenalan penutur. Pengujian FRR menghitung persentase aplikasi ketika tidak mengenali suara objek yang seharusnya dikenali. Persentase FRR dari masing-masing threshold dihitung berdasarkan rumus berikut:

$$
\text { Persentase } F R R=\frac{\text { Jumlah Suara Tidak Dikenal }}{\text { Total Suara }} \times 100 \%
$$

Berdasarkan perhitungan yang dilakukan melalui rumus, didapatkan persentase $F R R$ terbesar adalah $100 \%$ pada threshold 15 . Pada orang yang tidak terdaftar pada aplikasi, pengujian yang dilakukan adalah FAR. Orang yang dijadikan objek pengujian FAR adalah Riselda Lalusu. Data suara uji diambil berdasarkan suara yang direkam pada saat objek melakukan telepon dan terhubung ke aplikasi pengenalan penutur. Pengujian FAR menghitung persentase aplikasi ketika mengenali suara objek yang seharusnya tidak dikenali. Persentase FAR dari masing-masing threshold dihitung berdasarkan rumus berikut:

$$
\text { Persentase } F A R=\frac{\text { Jumlah Suara Dikenal Benar }}{\text { Total Suara }} \times 100 \%
$$

Berdasarkan perhitungan yang dilakukan melalui rumus, didapatkan persentase nilai $F A R$ adalah $100 \%$ pada threshold $30,35,40,45$, dan 50 . Berdasarkan pengujian FRR dan FAR yang telah dilakukan, maka disusun tabel yang merekap hasil kedua pengujian tersebut. Rekap pengujian mendasari pembentukan grafik hasil pengujian. Tabel rekapitulasi pengujian FAR dan FRR nilai ambang dapat dilihat pada Tabel 1.

Tabel 1. Tabel rekapitulasi pengujian FAR dan FRR nilai ambang

\begin{tabular}{|c|c|c|c|}
\hline No & Thershold & FRR $(\%)$ & FAR $(\%)$ \\
\hline 1 & 15 & 100 & 0 \\
\hline 2 & 20 & 90 & 10 \\
\hline 3 & 25 & 50 & 50 \\
\hline 4 & 30 & 0 & 100 \\
\hline 5 & 35 & 0 & 100 \\
\hline 6 & 40 & 0 & 100 \\
\hline 7 & 45 & 0 & 100 \\
\hline 8 & 50 & 0 & 100 \\
\hline
\end{tabular}

Nilai ambang yang dapat memaksimalkan hasil dari pengenalan penutur didapat dari nilai pada titik perpotongan FAR dan FRR. Berdasarkan grafik FAR dan FRR didapatkan nilai threshold 25 menjadi titik perpotongan pada pengujian. Pada threshold 25, nilai persentase yang dihasilkan adalah 50\%. Grafik FAR dan FRR dapat dilihat pada Gambar 16.

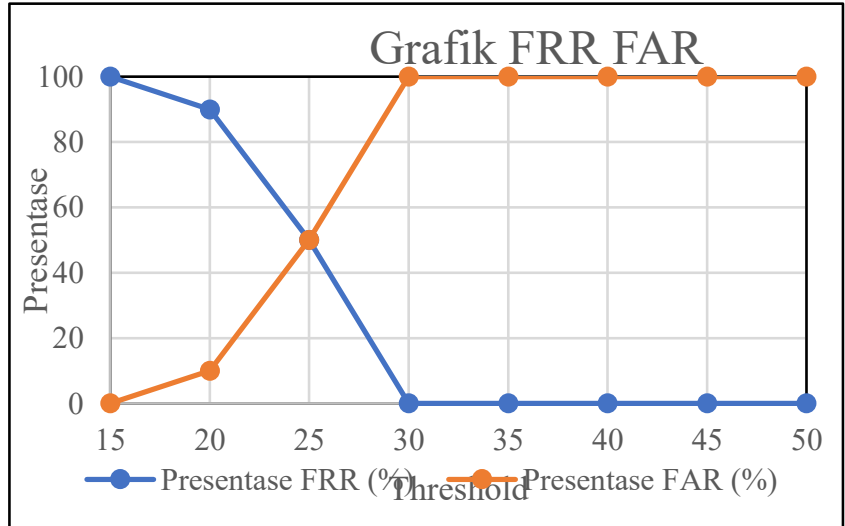


Gambar 16. Grafik pengujian FAR dan FRR

b. Pengujian Akurasi

Pengujian akurasi dilakukan dengan menguji sepuluh suara dari enam orang yang berbeda. Keenam orang yang menjadi objek pengujian terdiri dari tiga orang yang terdaftar sebagai data training aplikasi, dan tiga orang tidak terdaftar pada data training aplikasi. Objek pengujian yang terdaftar pada data training adalah Wahyu Patrika, Ifa, dan Muhammad Fahim. Objek pengujian yang tidak terdaftar pada data training adalah Riselda Lalusu, Batista Maryanto, dan Yolanda. Persentase akurasi dari objek yang terdaftar pada data training dihitung berdasarkan rumus:

$$
F R R=\frac{\text { Jumlah Suara Dikenali Benar }}{\text { Total Suara }} \times 100 \%
$$

Rumus nilai $F R R$ yang digunakan merupakan kebalikan dari rumus nilai $F R R$ pada pengujian nilai ambang. Persentase akurasi dari objek yang tidak terdaftar pada data training dihitung berdasarkan rumus:

$$
F A R=\frac{\text { Jumlah Suara Tidak Dikenali }}{\text { Total Suara }} \times 100 \%
$$

Rumus nilai $F A R$ yang digunakan merupakan kebalikan dari rumus nilai $F A R$ pada pengujian nilai ambang. Akurasi identifikasi suara penelepon pada aplikasi pengenalan penutur memiliki nilai persentase tertinggi yaitu $90 \%$ pada treshold 40,45 , dan 50 . Nilai persentase akurasi FRR tertinggi adalah $90 \%$ dengan rata-rata dari keseluruhan pengujian senilai $68,33 \%$. Nilai persentase akurasi $F A R$ tertinggi adalah $100 \%$ dengan rata-rata dari keseluruhan pengujian senilai $47,54 \%$. Nilai Rata-rata pengenalan penutur tertinggi berdasarkan pengujian $F R R$ dan FAR bernilai $80 \%$ pada treshold 25 . Hasil tersebut sesuai dengan pengujian nilai ambang, dimana nilai treshold 25 merupakan nilai titik perpotongan pengujian FAR dan FRR. Hasil rekapitulasi pengujian akurasi dapat dilihat pada Tabel 2 .

\begin{tabular}{|c|c|c|c|c|}
\hline \multirow{2}{*}{ No. } & \multirow{2}{*}{ Threshold } & \multicolumn{2}{|c|}{ Akurasi } & \multirow{2}{*}{$\begin{array}{c}\text { Rata-rata } \\
(\%)\end{array}$} \\
\hline & & FRR (\%) & FAR (\%) & \\
\hline 1 & 15 & 0 & 100 & 50 \\
\hline 2 & 20 & 47 & 90 & 68 \\
\hline 3 & 25 & 73 & 87 & 80 \\
\hline 4 & 30 & 77 & 80 & 78 \\
\hline 5 & 35 & 80 & 27 & 53 \\
\hline 6 & 40 & 90 & 0 & 45 \\
\hline 7 & 45 & 90 & 0 & 45 \\
\hline 8 & 50 & 90 & 0 & 45 \\
\hline \multicolumn{2}{|c|}{ Rata-rata (\%) } & 68,33 & 47,54 & 57,94 \\
\hline \multicolumn{2}{|c|}{$\operatorname{Max}(\%)$} & 90 & 100 & \\
\hline
\end{tabular}

Tabel 2. Tabel rekapitulasi pengujian akurasi

Hasil rekapitulasi pengujian akurasi digambarkan pada grafik akurasi. Grafik akurasi menggambarkan nilai $F A R$ dan FRR dari masing-msing treshold. Grafik akurasi dapat dilihat pada Gambar 17. 


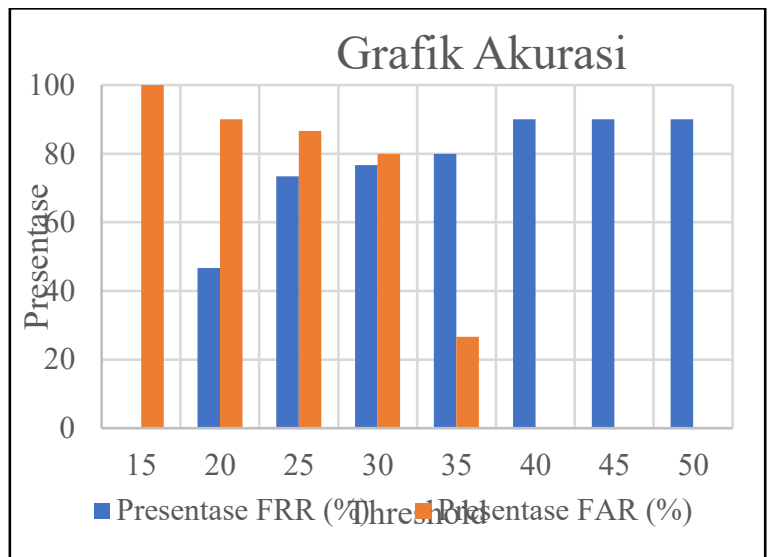

Gambar 17. Grafik pengujian akurasi

\section{KESIMPULAN}

Berdasarkan dari hasil analisis, perancangan dan pembahasan yang telah dilakukan sebelumnya, didapatkan beberapa kesimpulan yaitu:

1. Hasil penelitian ini mampu menghubungkan telepon pada layanan hotline dengan komputer. Suara penelepon yang masuk melalui telepon dikenali berdasarkan database dosen maupun staff pada komputer. Terhubungya telepon dan komputer memudahkan petugas dalam memonitor aktivitas telepon yang masuk pada layanan hotline.

2. Hasil penelitian ini mampu mengurangi resiko terjadinya ketidaksesuaian data penelepon yang disampaikan dibandingkan dengan identitas sebenarnya penelepon. Proses identifikasi penelepon pada aplikasi pengenalan penutur dilakukan dengan membandingkan ciri khas suara penelepon dibandingkan dengan ciri khas data latih suara dosen maupun staff yang terdaftar pada aplikasi.

3. Hasil penelitian ini mampu mempersingkat proses identifikasi penelepon pada layanan hotline. Penelepon yang telah teridentifikasi ditampilkan pada antarmuka aplikasi sekitar tiga sampai empat detik dari telepon masuk. Apabila dibandingkan dengan proses identifikasi yang berjalan pada layanan hotline saat ini, aplikasi pengenalan penutur memersingkat waktu sekitar enam detik.

4. Semua fungsi dari antarmuka pada hasil penelitian ini berjalan dengan baik berdasarkan pengujian black box. Pengujian menghasilkan persentase $100 \%$ berdasarkan penilaian 7 responden.

5. Metode Mel-Frequency Cepstral Coefficient dan Vector Quantization dapat mengidentifikasi suara penelepon dengan tingkat akurasi tertinggi yaitu $80 \%$ pada nilai ambang (threshold) 25 .

\section{DAFTAR PUSTAKA}

Apriyono, N., Wahyudi, W., \& Hidayatno, A. (2011). Pengenalan Pengucap Tak Bergantung Teks dengan Metode Vector Quantization (VQ) Melalui Ektraksi Linear Predictive Coding (LPC) (PhD Thesis). Jurusan Teknik Elektro Fakultas Teknik.

Mansfield, T., Kelly, G., Chandler, D., \& Kane, J. (2001). Biometric product testing final report. Contract, 92(4009), 309.

Munggaran, A. K., Djamal, E. C., \& Yuniarti, R. (2017). Identifikasi Suara Pengontrol Lampu Menggunakan Mel-Frequency Cepstral Coefficients dan Hidden Markov Model. In Seminar Nasional Aplikasi Teknologi Informasi (SNATI).

Prasetyawan, P. (2016). Perbandingan Identifikasi Pembicara Menggunakan Mfcc Dan Sbc Dengan Ciri Pencocokan Lbg-Vq.

Mustofa, A. (2008). Sistem Pengenalan Penutur dengan Metode Mel-frequency Wrapping. Jurnal Teknik Elektro, 7(2), 88-96. 
Schmuller, J. (2004). Sams Teach Yourself UML in 24 Hours (3 ed.). Indiana USA: Sams Publishing.

Sulistyorini, P. (2009). Pemodelan Visual dengan Menggunakan UML dan Rational Rose. Dinamik-Jurnal Teknologi Informasi, 14(1). 